\title{
How Economic Situation Affect the Decisions on the Building Energy Efficiency (BEE) Development in Malaysia ${ }^{1}$ ?
}

\author{
Queena K Qian ${ }^{1 *}$, Abd Ghani Bin Khalid ${ }^{2}$ and Edwin HW Chan ${ }^{3}$ \\ ${ }^{1}$ Endeavour Australia Cheung Kong Fellow, Center for Sustainable Design and Behaviour (sd+b), University of South Australia, Australia \\ ${ }^{2}$ Professor, Faculty of Built Environment, University Technology Malaysia, Malaysia \\ ${ }^{3}$ Professor, Building and Real Estate Department, The Hong Kong Polytechnic University, Hong Kong S.A.R., China
}

"Corresponding author: Queena K Qian, Endeavour Australia Cheung Kong Fellow, Center for Sustainable Design and Behaviour (sd+b), University of South Australia, Australia, Tel: +852-34008177; Fax: +852-23623979; E-mail: kun.qian@fulbrightmail.org

Received date: February 18, 2014; Accepted date: April 15, 2014; Published date: April 23, 2014

Copyright: (C2014 Qian QK, et al. This is an open-access article distributed under the terms of the Creative Commons Attribution License, which permits unrestricted use, distribution, and reproduction in any medium, provided the original author and source are credited.

\begin{abstract}
This paper analyzes how the economic uncertainty affects the stakeholders' decision-makings on Building Energy Efficiency (BEE) investment in Malaysia. It studies the underlying barriers that hinder the BEE market penetration. Interviews with 30 architects who have BEE working experience with developers in Malaysia were conducted to understand the uncertainties affecting the current situation and future prospects for BEE adoption from the aspects of economic uncertainty. The result shows that the government incentives are trustworthy and welcomed by the stakeholders. The good opportunity to improve the BEE market is during the economic transition stage. Malaysian has high confidence that government incentives will not be changed easily. The study also suggests possible policy solutions for overcoming the uncertainties to attain the large-scale energy-efficient building investment.
\end{abstract}

Keywords: Building Energy Efficiency (BEE); Economic uncertainty; Market barriers; Malaysia

\section{Introduction}

Building production and usage can be significant determinants of sustainable development. Environmentally, the building sector is responsible for high-energy consumption, solid waste generation, global greenhouse gas emissions, external and internal pollution, environmental damage, and resource depletion [1-4]. In Malaysia, the energy consumed in buildings is $90 \%$ in the form of electricity [5]. This is quite alarming as Malaysia has one of the fastest growing building industries in the world [6]. The Malaysian government has put in place the plans, strategies, initiatives and incentives to diversify the sources of energy for sustainable development $[7,8]$. However, there exist some challenges that hamper the development of sustainable energy and green buildings. There should be more concerted efforts in formulating the policies and strategies to further accelerate the deployment of energy efficiency sources and its related technologies. Energy Star (2013) recognizes that energy is the first step to green. Building energy efficiency (BEE) is thus one major component of Green building. The benefits from BEE are only vaguely understood by the general public and have not been widely pursued. The stakeholders still seem to hesitate about voluntarily entering the BEE market. Technological innovations contribute to BEE. However, it is estimated that with the current sophistication of technology, a better-designed policy package to promote BEE could increase effectiveness and efficiency by $40 \%$ [9]. A critical analysis of the current market situation and its future perspective will help understand the BEE policy development and rationales to better promote BEE.
This research aims to examine the role of uncertainty during economic transition that affects the stakeholders' BEE investment from TCs perspective, using the case of Malaysia. The study tries to understand the impacts of uncertainties on the decision-making of stakeholders in real practice of BEE market through interviews with the practitioners in Malaysia.

\section{Literature Review}

\section{BEE Embraced By Green Building}

As the environmental impact of building activities becomes more apparent, a movement called green building is gaining momentum. Green, or sustainable building, is the practice of creating and using healthier and more resource-efficient models of construction, renovation, operation, maintenance, and demolition (US EPA Green Building, 2008). As energy consumption in the building sector is one of the main components of total energy consumption in most countries [9-11], BEE becomes an important theme of green building, which brings together a vast array of practices and techniques to reduce the impact of buildings on energy consumption, the environment, and human health.

\section{The Barriers to BEE Causing Uncertainties}

With socio-economic progress, more building market stakeholders are getting involved and each of them looks after their own business interests which may have conflict with each other. Real estate developers generally do no more than just meeting the basic requirements of the law and policies, in order to minimize the costs of the extra work entailed by energy efficiency regulations. Contractors

1 An earlier version of this paper has been presented in the SB13 Dubai conference, 8-10, Dec, 2013, Dubai. The authors appreciate the feedbacks and comments collected from the discussion for improving the paper quality. 
also want to avoid these extra tasks, which require special expertise and specialized equipment that they do not typically possess. Manufacturers of BEE products want regulations to be even stricter to create greater demand in the market. Financially, building-design professionals and their institutes will not be adversely influenced by the new policies but are apt to succumb to the demands of developers due to the nature of their relationship. These conflicting interests are the main sources of the uncertainties concerns and the barriers to BEE development. The unique barriers to the BEE market, including the longevity of life causing slow innovation adaptation; Low level standardization requiring trustworthy performance; extended supply chain; bounded rationality; risk aversion; negative externalities; split incentives; public goods; cash flow constraints; information uncertainty; unaware of the hidden costs, can be established from extant studies [9,12-15].

\section{Economic Uncertainty}

Uncertainty Staley [16] plays a vital role in the stakeholders' decision-makings of their BEE investment [15]. Uncertainty due to information asymmetry is the fundamental aspect of transaction costs theory, which will be verified from interview data. On the supply side, the developer has to search detailed information about strategies of his opponents before he decides to invest in BEE. The searching process may incur high uncertainty that even prevent him from entering the market. The primary reason is that the degree of compliance of BEE code cannot be perfectly observed from the public, and some developers may exaggerate the energy efficiency performance. The extreme case is to sell the conventional building product at the price of BEE, which would fill the BEE market with a lot of fake and lowquality non-BEE products. As practical evidences show, the inability to distinguish the BEE from the non-BEEs and the constant doubt from the public further undermines the attractiveness of BEE to stakeholders and eventually leads to a "Lemon market". Moreover, the external factors, such as the stability of economic and policy environment, will also cause the concerns of the stakeholders in their decision-making process on BEE.

In Malaysia, Samari observed that the current financial incentives are not able to cover the high upfront cost of green buildings [8]. Only Architects association Malaysia has developed the green building index for Malaysia and other than that very little initiative has been made. Green activist group Malaysia has also made some initiatives to promote green cities but not much has been done. A zoom-in focus of the building industry in Malaysia gives an insightful perspective of BEE market development in developing Asian countries. Through interviews with the professionals we may have a better understanding the impacts of economic uncertainty to BEE market.

\section{Methodology}

\section{Interview with the Architects in Malaysia}

In-depth interviews to solicit views and issues regarding BEE investment were conducted with the architects, who have BEE working experience with developers in Malaysia. The research team travelled to Malaysia in 2012 and met the potential interviewee, through a CPD event and guest lecture on BEE to the Malaysian Institute of Architects (Pertubuhan Akitek Malaysia-PAM)-which was contacted through University Technology of Malaysia (UTM), and Construction Industry Development Board CIDB of Malaysia. After screening to ensure the interviewees with BEE working experience, the team interviewed 30 architects, who have actively worked on BEE projects for major real estate development companies in Malaysia. The purpose of the data collection was to get the first hand opinions of architects with BEE project experience about the role of economic uncertainty in BEE investment, especially during the economic transition period. The data analysis also provides a better picture of BEE market development relating to a specific institution in the Malaysia case, and provides reference for designing rational policy. The responses from these architects are important to understand the market/business expectation from a more objective perspective.

\section{Interview Questions Design}

The hypotheses and the interview questions were developed based on the literature review as presented above and through pilot discussions among the research team members and with 2 experts in industry and 2 academics. The relations between the three aspects of economic uncertainties, two hypotheses $(\mathrm{H})$, and three interview questions (Q) are listed in Table 1 below. The purpose of these interviews is to understand how the uncertainty affects the BEE investment decisions by a case study of Kuala Lumpur of Malaysia with the local architects' viewpoint, which ascertains the impact of economic transition to BEE development in practice. What is the impact of economic transition on the BEE development (to the developer-H1; to the government-H2)? Is it a challenge or an opportunity? How do the developers' concerns change in an economic downturn or upturn? What should government be alert to during such periods and how can it develop the most effective policies to promote BEE accordingly? These are the main issues that are addressed in interview questions Q1- Q3.

\section{Empirical Analysis and Interview Results}

Table 1 shows the major opinions (extraction of the top ranked points from the collection of answers) of the interviews, which have been summarized and grouped under a few dominating points in the "Summary of the Key Responses" in Table 1. It was an interview exercise where the respondents could give several options or views to one question. The rate of respondents with the views close to the summarizing key point is shown in the right hand column of the table. The $\%$ rate shown for the answers of each question shows the weighted similar opinions to each interview question among the interviewees, which cannot be taken as comparison with another question in absolute value or importance. The interviewees are free to have multiple answers to each interview question, as long as they do not conflict with each other. Therefore the percentage of the different views to each question does not necessarily add up to $100 \%$. Those Key Responses highlighted in bold letters are the significant issues to be discussed in more details in the discussion section.

H1; The economic context (upturn or downturn economic transition) affects the concerns of the real estate developers about BEE investment.

\begin{tabular}{|l|l|}
\hline Questions & Summary of the Key Responses \\
\hline
\end{tabular}


Q1 At "economic transition" period/stage (upturn or downturn), what are the new challenges or opportunities to developers in investing GB/BEE? How do shifts (upturn or downturn) in the economy change the developers' major concerns (neutral, positive, or negative) and in which aspects?

\begin{tabular}{|c|c|}
\hline $\begin{array}{l}\text { It depends on the planning, priority and value judgment of the corporation and individual } \\
\text { decision-maker. }\end{array}$ & \\
\hline $\begin{array}{l}\text { When products become harder to be sold in the market (less demand, more competition), } \\
\text { green building can be competitive advantage which is not necessary in times when products } \\
\text { are easy to be sold. So, there will be more incentive to go in green building. }\end{array}$ & $23.07 \%$ \\
\hline Can do more, faster and put more resources in GB/BEE in the economic upturn. & \\
\hline More challenges than opportunity in the downturn. & \\
\hline $\begin{array}{l}\text { During the economic downturn, the developers are more willing to do the energy retrofits, } \\
\text { because it's much quicker to get the capital return back. }\end{array}$ & \\
\hline $\begin{array}{l}\text { When it is economic downturn, the developers will be more conservative/ reluctant to do any } \\
\text { innovative project including green features due to limited budget; while in its upturn, they will } \\
\text { be more likely willing to invest in GB/BEE. }\end{array}$ & $15.38 \%$ \\
\hline $\begin{array}{l}\text { Economic downturn is a better chance to further the GB/BEE development, because people } \\
\text { expect changes; however, in the economic upturn, everything is prosperous, and why would } \\
\text { the developers change their regular earning formula of their investment. }\end{array}$ & \\
\hline $\begin{array}{l}\text { The government should take the opportunity in the economic downturn to shout loud to } \\
\text { promote BEE/ green, as it is more an opportunity than a challenge to further its development. }\end{array}$ & \\
\hline $\begin{array}{l}\text { The previous economic downturns maybe different from the current one, because the green } \\
\text { movement is not as heat-up as it is now. Therefore, it more depends on the individual } \\
\text { developer and its own capital capacity and business strategy to integrate green features into } \\
\text { the practice. }\end{array}$ & \\
\hline $\begin{array}{l}\text { Need more government incentives, money wise, to promote GB/BEE to the developer; and } \\
\text { education wise, to the whole public. }\end{array}$ & $37.50 \%$ \\
\hline $\begin{array}{l}\text { Both the government and the developers should have long term views and will invest in } \mathrm{GB} / \\
\text { BEE, even in economic downturn. }\end{array}$ & $47.50 \%$ \\
\hline $\begin{array}{l}\text { At the economic down-turn, the developer would mainly improve the "green" image to add to } \\
\text { their brand-name, but the result is not very significant. Because the approach attracts mainly } \\
\text { the user-buyers, not the speculators, and developers want to have more speculators for } \\
\text { profits than the user-buyers. }\end{array}$ & $2.50 \%$ \\
\hline
\end{tabular}

$\mathrm{H} 2$ Changes in economic conditions (upturns and downturns) call for the attention of government to adjust BEE policies as necessary to seize BEE development opportunities.

Q3 What role should government play and what GB/BEE promotions or incentive could government introduce in times of economic change that would be less upsetting to the market players' normal activities?

During the economic up-turn, government incentives or promotion are less effective than the
down-turn, because the property sells well and the buyers are less concern about green
features.

Table 1: Key Interview Responses on the economic uncertainty of BEE.

\section{Observations on the Findings}

Regarding Q1, the respondents had a wide range of viewpoints about new challenges and opportunities at times of changing economic conditions: $25 \%$ of the respondents opines that "It all depends on the planning, priorities, and value judgments of the corporation and individual decision-makers", and $23.07 \%$ believes that "When products become harder to be sold in the market (less demand, more competition), green building can be competitive advantage. So, there will be more incentive to go in green building". It shows that they collectively agree that the overall decision making depends on the real estate developers business concerns, however, the government incentive has a key role to play. $15.38 \%$ of the interviewees thinks that "economic downturn, the developers will be more conservative/ reluctant to do any innovative project including green features due to limited budget; while upturn; they will be more likely willing to invest in GB/BEE", which echoes with only $5.77 \%$ agree that "An economic downturn is a better chance to further BEE development", because people expect change; whereas, in economic upturns, everything is prosperous, developers have little reason to change their regular earnings formula to try something new and risky. However, if the government takes the opportunity of the economic downturn to promote BEE vigorously, it is recognized that conditions present more of an opportunity than a challenge (15.38\%). A further $9.62 \%$ provide a view based on a local example: "In this economic downturn in Malaysia, the developers are more willing to do energy retrofits, because it is much quicker to get the capital return back". 
Regarding Q2, 47.5\% respond that "Both the government and the developers should have long-term views regarding BEE and will, even in economic downturns". To achieve this, $37.5 \%$ think that the BEE market "Need more government incentives, money wise, to promote $\mathrm{GB} / \mathrm{BEE}$ to the stakeholders; and education wise, to the whole public". In addition, $12.5 \%$ express a more conservative view; they think "This economic downturn may be different from earlier ones, because the green movement was not as popular as it is now". However, only $2.5 \%$ believe that "In the economic downturn, developers would want improve their reputation for being green to add to their brand name, but the end result would not be very significant, because it attracts mainly the user-buyers, not the speculators. The developers want the speculators for profits more than the user-buyers". Therefore, integrating green features will depend more on the individual developer, its capital capacity, and its business strategy".

Regarding the role that government can play during times of economic change, the majority views $(41.86 \%)$ agree that basically, "During the economic downturn, government incentives are more important, because the developers are more reluctant to invest in green and end-users who buy also need to be more assured by the cost benefits from green incentives". There is striking alternative views $(34.88 \%)$, believe that, "Steady and gentle growth, i.e., economic upturn, would be the best time for developers to invest in BEE and the best time for the government to promote BEE, too". $20.93 \%$ of the interviewees, however, disagree with the above with the reason that "during the economic up-turn, government incentives or promotion are less effective than the down-turn, because the property sells well and the buyers are less concern about green features".

\section{Discussions and Recommendations}

Economic conditions (upturns or downturns) call for attention by the government to adjust BEE policies in order to promote BEEdevelopment. During economic downturn, the developers are less interested in green investment due the limited budget. The government incentives are more important at this situation to boost the BEE market; meanwhile, people who buy also need to be assured of getting the real benefits of green incentives. Although the decisionmaking on investing in BEE depends on the real estate developers' business concerns, the government incentive has a key role to play. Besides, a long term vision and consistency of both the government and the market regarding the BEE development with a fully deployed package of BEE policies are solid foundation for the healthy BEE market development.

Generally, the study shows that there is a call for turning to stricter guidelines and requirements for BEE, and a variety of policy tools including appliance standards and labeling, building energy code, building energy performance rating and certification, financial incentive, government demonstration, awareness raising etc., are being utilized in Malaysia. Comparing to developed countries, policy for BEE in Malaysia is still at a very early stage of development. A wellestablished institutional infrastructure to support the implementation of the building energy codes is yet to be established. In the building sector, it needs a more concrete policy and focused strategy to increase the acceptance of energy efficiency measures. The government should have long-term strategies and clear and consistent policy for BEE promotion, to create a positive investment environment and raise the stakeholders' confidence and the market's expectations for business investment in BEE. Market stakeholders want the government to take the lead to try out BEE projects to cut down any uncertainty before they join the investment.

\section{Conclusion}

This study examines the stakeholders' concerns on BEE investments due to the economic transition period and has focused on uncertainty in particular. The research employed an interview survey with architects in Malaysia. The data provides a list of findings as they apply to the case of the Malaysia BEE real estate development. The study reveals the market situation and suggests policy solutions to address the concerns of uncertainties to promote BEE.

\section{Acknowledgements}

The work described in this paper was supported by research grants provided by The Hong Kong Polytechnic University and University of Technology Malaysia. The authors would like to thank all those who contributed to the interviews and those who contributed in reviewing the manuscript.

\section{References}

1. CICA (2002) Confederation of International Contractors Associations: Industry as a partner for sustainable development UK :1-60.

2. Zimmermann M, Althaus HJ, Haas A (2005) Benchmarks for sustainable construction - a contribution to develop a standard. Energy Build 37: 1147-1157.

3. Melcher L (2007) The Dutch sustainable building policy: a model for developing countries? Building and Environment 43: 893-901.

4. Ortiz O, Castells F, Sonnemann G (2009) Review sustainability in the construction industry: a review of recent developments based on LCA. Construction and Building Materials 23: 28-39.

5. Zainordin N, Abdullah SM, Baharum ZA (2012) Users Perception towards Energy Efficient Buildings. Asian Journal of EnvironmentBehaviour Studies 3: 91-105.

6. ABCSE (2005) Renewable Energy in Asia Malaysia Report. Australia.

7. Atsusaka N (2003) Growing the green building industry in Lane County program for Watershed and Community Health. Institute for a Sustainable Environment University of Oregon USA.

8. Samari M, Godrati N, Esmaeilifar R, Olfat P, Shafiei MWM (2013) The Investigation of the Barriers in Developing Green Building in Malaysia. Modern Applied Science 7: 1-10.

9. OECD (2003) Environmentally sustainable buildings, challenges and policies. OECD publications Service France.

10. Chan EH, Lau SS (2005) Energy conscious building design for the humid subtropical climate of Southern China, Green Buildings Design: Experiences in Hong Kong and Shanghai. Architecture \& Technology Publisher China: 90-113.

11. Zhang QY (2004) Residential Energy Consumption in China and its comparison with Japan Canada and USA. Energy and Buildings 36: 1217-1225.

12. Jaff AB, Stavins RN (1994) The emerge-efficiency gap: what does it mean? Energy Policy 22: 804-810.

13. Bell M, Lowe R, Robert P (1996) Energy efficiency in housing Aldershot Avebury.

14. Finkel G (1997) The economics of the construction industry Sharp London and New York.

15. Qian QK (2012) Barriers to Promote Building Energy Efficiency (BEE)A Transaction Costs (TCs) Perspective.

16. Staley SR (1998) Ballot-box zoning, transaction costs and land development. Urban Futures Working Paper No: 98-102. Los Angeles CA: Reason Public Policy Institute. 